\title{
3
}

\section{INDIGENOUS FUTURES}

\section{The practice of sovereignty in Nagaland and other places}

\author{
Arkotong Longkumer
}

\section{Introduction}

Sovereignty: people, freedom; land; place-making; authority; God; obedience; unity; surrender; suffering; sacrifice; prayer; prophecy; encounters; becoming; futures.

These words appear in the lexicon of my thinking about sovereignty. They cut through the encounters and stories I have gathered through the warp and weft of the Naga national fabric, and through encounters in the global ecumene. ${ }^{1}$

The year is 2005. After an exhausting time at a pilgrimage site in the south of Assam, Cachar district, bordering the state of Manipur, along with friends, we drive eastwards towards Manipur and reach a town called Jiribam. Part of the intention of entering this town - the features of the place now hazy in my memory - was to find our way to a Rongmei Naga village called Langkao, the birthplace of the famous Naga prophetess, Rani Gaidinliu. Perhaps due to the fresh mountain air of the pilgrimage site, the intermingling of people and the sharing of food, the heady concoction of alcohol and hashish, we were blissfully unaware of the geo-political situation awaiting us in Jiribam. Following local protocol of making our travel journey known to a Naga nationalist group, the National Socialist Council of Nagaland, Khaplang (NSCN-K), since it controls much of the countryside of Jiribam, we found ourselves in a tangle with the town commander, a self-styled regional 'big man'.

Unable to accept our reasons for journeying to Langkao, we were branded as 'spies' of their rival group, the NSCN-Isak/Muivah (IM), blindfolded, and taken to their camp for interrogation. Once our blindfolds were removed, we noticed we were in a different locality - several huts, a fishing pond, and men with wireless radio receivers, busy exchanging words, perhaps trying to corroborate our story of being innocent researchers, in the wrong place at the wrong time? During the hour-long interrogation, I sensed that they were partly roughing us up to 
demonstrate a certain disdain for us 'bourgeoisie', far removed from the struggle for Naga independence that these young men were committed to. They kept asking me, "Do you know anything at all about the Naga national struggle?" Or, "What would you know about our sacrifice?" Indeed, what would I know of their experiences or their feelings towards 'Naga sovereignty'? At that time the concept sounded far removed, the idea too entangled with our treatment from these 'nationalists' we had encountered. I kept wondering if all of this was worth fighting for, given that any outsider is a threat to their very existence. When all was settled - that we were indeed innocent researchers on a mission - our foes turned friends, just like that! A dog was killed in our honour for feasting, and a chaplain appeared to preach to us about Naga nationalism, asking us time and again to pray for them. Our possessions were returned - a quick glance at my wallet necessitated a comment from the chaplain: 'We are not thieves you know, we are national workers'. I noticed that a 500-rupee note was missing but restrained myself from making any accusations. Leaving the place, I thought that at least now I had contributed something to their cause!

Although I was quick to judge my fellow Nagas in their quest for nationhood, my view tainted by my then-recent experience that touched on the dark side of nationalism, I was also reminded of the many stories I had heard since childhood - stories of bravery, sacrifices, and togetherness. Seeking to move beyond these general sentiments of Naga nationalism, I decided to embark on a different journey, one in which I wanted to hear those untold stories, those moments that brought to life a thinking and feeling about sovereignty. These encounters were mostly spontaneous, unplanned, but unravelled before me. I seemed to be in the right place at the right time. My experience in Jiribam sharpened my understanding of Naga nationalism in ways that I could not have imagined over the subsequent years.

After a gap of almost ten years, in 2014, in a chance encounter I met two men from a prayer centre called Sumi Alakishi Kighinimi (a Christian Sumi Peace Prayer Cell; hereafter SAK). The story goes something like this: I was having lunch with a friend of a friend in Dimapur about my research into Naga sovereignty. He invited me to meet some people he was meeting later in the afternoon who might enlighten me. I met the two men from SAK and we exchanged phone numbers. Usually I follow up on these leads, but on this occasion, they initiated contact. In a week's time, they invited me to their centre, in Ghatashi, a Sumi Naga village in the district of Zunheboto, a few hours drive north from Kohima, the capital of Nagaland. Uncertain of what to expect, or why I was even being entertained, I stepped out of the car into the bright morning sun to be welcomed by a group of men and women - prayer warriors - in their finest clothes, with tea and biscuits laid before us in anticipation of our visit. With these words, I was welcomed:

This is a prophecy that is not a few days old. It has been said. Praise the Lord. That's why the people are ready and waiting here. This is a fulfillment. I 
will send a person from foreign lands to come and interview - though a name was not shared - and that person will interview and ask you about the beginning of our prayer centre.

The prophecy of my coming to a prayer centre, a national prayer centre for the Nagas, discloses another logic of thinking about sovereignty. Do I share in some essence of sovereignty, like many of my interlocutors do, distributed across time and space? Can my involvement be a way to translate their world of prophecy into a language of policy and political theory? I start with these moments to explore the complex nature of time, of sovereignty, and what they mean to the Naga nation. From being roughed up and coming face to face with the realities of the Jiribam nationalists, to being welcomed, because my presence was prophesised in Ghatashi - these are indeed unnerving events that will make any person think. On both occasions 'being in time' mattered to the unfolding of events.

First, this chapter explores three vignettes that give flesh to practices of sovereignty - through visions and landscapes, place-making, and a national prayer centre. In all three examples I examine how sovereignty is envisaged in a sentient landscape, where national futures are powerfully evoked and experienced. I use the idea of the 'common world' of cosmopolitics to suggest that a practice of sovereignty occurs amongst different actors - people, landscape, materialities, deities - that is always in the process of becoming. Second, I turn my focus to the global situation to try and disentangle the complex web of encounters and shared experiences amongst different indigenous communities through transnational travel.

Through the five-year project, Indigenous Religion(s): Global Networks, Local Grounds (INREL), I began to look comparatively at other research sites as I examined a key question: How does sovereignty relate to notions of belonging? In order to answer this question, I develop this idea of sovereignty in motion, both in terms of our physical exposure to different research sites, but also how it materialises and expresses itself in diverse locations. By understanding sovereignty in motion, my research context was also enriched. It allowed me to appreciate the way sovereignty is about becoming, rather than capitulation to fixity. Conceptually, it may be attractive to be drawn by certain ideas of sovereignty such as territorial independence, neat national boundaries, common language, culture, and religion - but sovereignty as practice and as becoming allows alternative practices of time, not simply reducible to the clock and the calendar, but to think of multiple temporalities at once and how these multiple temporalities contribute to the realisation of sovereignty. Here, I am reminded of the eloquent words of Joao Biehl and Peter Locke in their edited volume, Unfinished: The Anthropology of Becoming:

Becoming occupies its own kind of temporality that unfolds in the present: a dynamic interpenetration of past and future, actual and virtual. Distinct from potentiality and not reducible to causality or outcomes, becoming is 
characterized by the indeterminacies that keep history open, and it allows us to see what happens in the meantimes of human struggle and daily life.

Paying attention to our interlocutors and their shifting practices, and the multiple forms these experiences take, becoming is about how these storied histories persist, folded into sensibilities, perceptions, encounters, and dwelling. I use research sites such as Sápmi (Norway), Talamanca (Costa Rica), and Hawai $i$ (USA) to give flesh to these global encounters, keeping in mind the way locally inflected cultural aspirations are articulated in the language of indigeneities. Paying attention to global networks of becoming, I look at how the 'local' in its freighted nature of place-making collides with and complements the 'common world' of indigeneity through the interaction of humans and non-humans. I pay attention to their capacity to elicit indigenous futures as a way of being in the world. By indigenous futures I look at the productive ways people orientate their lives across time and space, rooted in the materialities and the sentient ecologies of everyday life. It attempts to understand the role of the future in their temporal sense of anticipation, risk, prophecy, and knowledge. After all, national futures are crucial to many indigenous peoples. And in this chapter I show the relationship between collective pasts and their anticipated futures as they converge into perpetual becoming (Bryant and Knight 2019; Bear 2016; Munn 1992).

\section{Indigenous timescapes}

This chapter begins by advancing notions of how indigenous timescapes provide a cosmopolitics or a 'common world' (Latour 2004), where humans and nonhumans participate in ways that might appear odd in historical narratives. This is a challenge that the historian Dipesh Chakrabarty proposes, in his now classic examination of the historical difference between Europe and the Global South. In Provincializing Europe (2000), Chakrabarty argues that subaltern narratives remain partially unrepresented within the academic discipline of history. Part of the lack is due to the elision of non-human actors in the making of subaltern history beyond the purely 'social'. Chakrabarty urges us, first, to reconsider the "secular conceptions" (2000: 15) of the social and political. Not only do humans exist in a "single and secular historical time that envelops other kinds of time", but drawing on a South Asian example, historical time itself is not integral, he says, to the fashioning of events (Chakrabarty 2000:108). Rather, it is important to pay heed to heterogeneities without seeking to reduce narratives to an overarching principle "that speaks for an already given whole" (Chakrabarty 2000: 108). There is no universal history, or a pre-arranged set of criterion that speaks to a particular model. Divergences, critique, and nuance must be taken account of in order to speak for different pasts, presents, and futures. Second, Chakrabarty asks us to question the premise that the "human is ontologically singular, that gods and spirits are in the end "social facts" (2000: 16). Suspending this 
judgement is crucial, argues Chakrabarty, because human entanglement with gods and spirits is pervasive throughout history (2000: 16). Indeed, and importantly, he makes the point that one must not simply relegate gods and spirits to beliefs, but, rather, considers how they affect social practice as historical cause (2000: 105).

The intervention by Chakrabarty with regard to privileging 'subaltern pasts' and the cosmopolitics that Bruno Latour speaks about are similarly constituted: both attempt to democratise politics and the social sciences through the inclusion of non-human actors (see also Viveiros de Castro 1998; Stengers 2005; de la Cadena 2015). This approach takes seriously subaltern narratives as a way of understanding indigenous sovereignties that may not always accord with established historical paradigms. If time is differently conceived by indigenous peoples across the world as they inhabit, imagine, perform, and believe in their right to sovereignty, so " $[\mathrm{t}]$ ime, as it were, thickens, takes on flesh, becomes artistically visible” (Bakhtin 1981: 84-85). In other words, the experiences of 'time space' (or chronotope) through bodies that live in the moments of history inhabit the temporal and spatial matrix that "becomes charged and responsive to the movements of time, plot and history" (Bakhtin 1981: 84-85). This means that simply viewing sovereignty as a lofty concern to do with political theory, and economic nationalism, takes away its potency, especially as it criss-crosses time and space, and muffles those very voices, the narratives of people. Michel de Certeau elegantly evokes what I mean by this juxtaposition: "What the map cuts up, the story cuts across" (1984: 129). In other words, rather than abstract principles concerning what sovereignty implies, this chapter seeks to bring to light sovereignty as a part of "the world as it is known to those who dwell therein" (Ingold 1993: 156). Stories preserve the workings of groups. Rather than simply theorising and explaining, this paper elaborates on the nature and practice of sovereignty.

\section{Political and historical rhythms}

According to the political scientist James C. Scott (2009), this upland region, stretching from South/Southeast Asia and the Himalayan region (called Zomia) is the world's largest remaining non-state space. Comprising roughly 80 million in population, Zomia has actively resisted incorporation into the classical lowland state, the colonial state, and the independent nation-states that have emerged after World War II (Myint-U 2011). This resistance has given rise to secessionist movements, indigenous rights struggles, millenarian uprisings, and armed insurrection against the post-independent states. The Nagas are an important example of the struggle for indigenous peoples' rights to sovereignty in the Zomia region.

Described as being located at the 'periphery of the periphery on the road to nowhere' (Verghese 1997), the Nagas live between the lower ranges of the Eastern Himalayas in the borderlands of Northeast India and Northwest Myanmar, and 
speak a variety of Tibeto-Burman languages. Approximately 2 million Nagas live in India, and 100,000 in Western Myanmar. The first written proclamation of Naga sovereignty came in 1919; this was then encapsulated in 1929 in the work of the British Simon Commission and used thereafter in proclamations for self-determination:

We pray that the British Government will continue to safeguard our rights against all encroachments . . that we should not be thrust to the mercy of the people [i.e. India] who could never have conquered us themselves, and to whom we are never subjected; but to leave us alone to determine for ourselves as in ancient times.

(Alemchiba 1970: 164)

The Naga historical movement is thus seven decades old. When India gained independence on 15th August 1947, the Nagas of India requested that they be left alone, outside of the Indian union. Led by the President of the Naga National Council (NNC) and their leader, A.Z Phizo, they met the two prominent Indian representatives, M.K. Gandhi and Jawaharlal Nehru, regarding the future of the Nagas outside the Indian union. The former, Gandhi, said that the Nagas were free to choose their destiny, according to NNC accounts, while the latter, Nehru, was adamant that the Nagas were a part of the union. This caused a stalemate, which led to the Nagas declaring their independence on the 14th August 1947, a day prior to Indian independence. In a massive show of strength, the Nagas conducted a plebiscite on the 16th May 1951, which reported that $99 \%$ voted in favour of Naga independence. This plebiscite was held in the context where independence and the negotiations surrounding it were not supported and recognised by the Indian state. The intransigence of both parties further aggravated the situation, resulting in the mass mobilisation of Indian security forces and apparatuses since the 1950s, and the beginning of armed skirmishes that remain a reality till today.

Since then the Nagas and the Indian state have been in conflict over the nature of Naga independence, leading eventually to a cease-fire between the two main parties - the Government of India and the National Socialist Council of Nagalim - Isak/Muivah (NSCN-IM) faction in August 1997. The Naga national movement over the seven decades has fractured into several groups - nine in total, though the NSCN-IM and the NSCN-K remain the two most powerful groups - due to different regional and personality clashes. However, the overall ideology of Naga sovereignty has been maintained amongst the different Naga factions. The Naga movement is thus one of the longest freedom struggles in modern political history. This is how a renowned human rights activist encapsulates the movement:

The Naga history is soaked with blood and tears, pain and sorrow, wounds and scars. Our fathers, mothers, brothers, and sisters have paid the price! Haven't we all heard - stories of villages burnt down to ashes, parents 
with children driven to jungles, men tortured and put to death, women molested and raped. Many orphans and widows left behind to a life of struggle.

(Aier 2011: 36)

The Naga conflict remains unresolved. The nine Naga factions claim to represent the 'authentic' rights of the Naga people; further, the Nagas live in four separate Indian states and in Western Myanmar, thus complicating the kind of sovereign settlement that is possible beyond these arbitrary nation-state boundaries; a situation not uncommon amongst other indigenous peoples (Jung 2008; Muehlebach 2001; Shaw 2008). Focusing on timelines, political events, and issues pertaining to governance limits an exegesis of the nature of sovereignty, particularly as it is thought of and felt. Sovereignty as an exercise lived out through human pain, emotion, sorrow, and promise, wrinkled through time, is what undoes the power of state-making and questions the very nature of the temporal, and historically constituted, nation-state. I turn now to stories that make this thinking about sovereignty habitable.

\section{Time and flesh}

\section{Vignette 1: visions and landscape}

On a hot summer's day in Dimapur, a dusty urban town in the state of Nagaland, I drive towards the border with Assam to a place called Universal Prayer Centre. ${ }^{2}$ At this Christian retreat centre built by a wealthy Naga family just inside the border with Assam, I meet several of the members as we discuss visions, prophecy, and how these connect with national life. As we are finishing our conversation, an elderly man in his 70s enters the room with a walking stick, sits down, and speaks about the importance of prayer to the national struggle. There is a sparkle in his eyes that shows wisdom, knowledge, and experience cultivated over many years. He invites me back to his room in the prayer centre to continue our conversation.

There is a rickety old bed, a couple of chairs, and a wardrobe that has aged considerably, visibly eaten by termites. The mud floor has a jute sack that is used as a mat for his dog. He shows me his jaw, now wrecked with old injuries.

When I was captured by the Indian army in the early 1960s for being a part of the NNC, I was jailed for 37 days. They crushed my face severely with their boots that now I find it hard to open my mouth properly.

(Chungshi, interview, Karbi Anglong, October 2014)

He told me that he was the commandant of an NNC battalion; he had been called upon to join the NNC due to his training in the Assam police. "There was news", he says, "that our people were being killed and tortured and Naga villages were being burnt" (interview, Karbi Anglong, October 2014). He begins to tell 
me about his time in the battalion, recalling how a woman from Kohima came to Mokokchung (a town in central Nagaland) and challenged the youth to join the NNC. He remembers the time in the 'jungle' and the constant movement of the cadres, due to the pressure from the Indian military. Some people died, according to Chungshi, due to malnutrition, dysentery, and malaria because they did not have proper medicine in the jungle camps. But, he takes time to emphasise, the struggle for sovereignty relied on God's guidance.

Not only is Chungshi a NNC stalwart, but he is also an arasentzur (Ao. diviner). ${ }^{3}$ As a young boy he could heal, had visions that were fulfilled, and also had the power of foresight. He narrates to me the daily routine in these NNC jungle camps:

Every time we moved, we would pray and read the Bible. Because I had the gift of vision (as an arasentzur), I would sometimes say, "We shouldn't go as it is 12 noon; if we do, we will be attacked by the Indian military". Signs were also clearly shown to me. One time, despite my warnings, the NNC battalion decided to proceed to attack an Indian army camp. We encountered three events along the way - we came across a landslide; rain, wind and sun occurred at the same time; and finally we saw a tiger attack a wild pig, but it left without eating the flesh or drinking the blood. These were bad omens and I persuaded the battalion to turn back. Thus we were saved. God is faithful to us.

(interview, Karbi Anglong, October 2014)

Chungshi's experience of these events displays an ability to apply the knowledge and skills that he has inherited through his role as an arasentzur, but also his ability to merge that into his Christian identity. Sensing the way the landscape, nature, and animals move around him provides signs, imprinted also in dreams and visions, and demonstrates the way people and landscape are mutually constituted elements of what it means to be 'of the land'. When I asked him why he came to the prayer centre, he spoke of his sin, the atrocities he committed unknowingly on innocent Naga villagers, the killing of Indian soldiers, and his desire to possess land belonging to his ancestors. This desire, he says to me, haunts him even today because when "God is alive, you cannot claim that it's your land. I still see in a vision the lay of the land -6 by 3 feet - and I am frightened" (interview, Karbi Anglong, October 2014). Land - as a gift from God and the ancestors - is what Chungshi fought for all these years, even without mentioning the word 'sovereignty'. And now, in his old age, this is how he spends his time, in penance, in prayer, for the nation.

God has forgiven me [for the sins described above] but there is still dirt in me and that's why I entered the prayer centre and I said to God whatever the Naga people have done, please show it [to] me and I will pray for them. From midnight till 6am, I pray for the Naga nation and for the world. If you pray everyday then that's good. If you pray for your clan, family or 
tribe then that's not enough; it's only skimming the surface. [This is what God says]: "Once you pray for the whole world then you will understand me in more depth. And I will bless you". So that's why I first of all ask for forgiveness and then I pray for the nations of the world.

(interview, Karbi Anglong, October 2014)

\section{Vignette 2: place-making}

From afar the NNC Transit Peace Camp in Kohima village looks like a military enclosure (Figure 3.1). Upon entering, time stands still. There is a gate and a check post manned by a guard, and inside the premises are living quarters for the NNC cadres who signed the Shillong Accord in $1975 .^{4}$

Most of the cadres are now old but still don their military fatigues and wear their medals with pride. We are taken around by the Speaker of the NNC, who shows us the camp and introduces us to the NNC chaplain, who is also wearing a camouflage army jacket. As we sit around the large conference desk for a chat over tea and biscuits, the chaplain says "thanks to God for the 3 of you here" referring to our guide (the NNC Speaker), a friend, and me. He continues, "I had a vision before the 3 of you came here. I made this drawing, which I'm giving to you" (Figure 3.2).

In this drawing, it shows the personification of death, symbolised by a human face as the heart, who is filled with rage and will come and bring

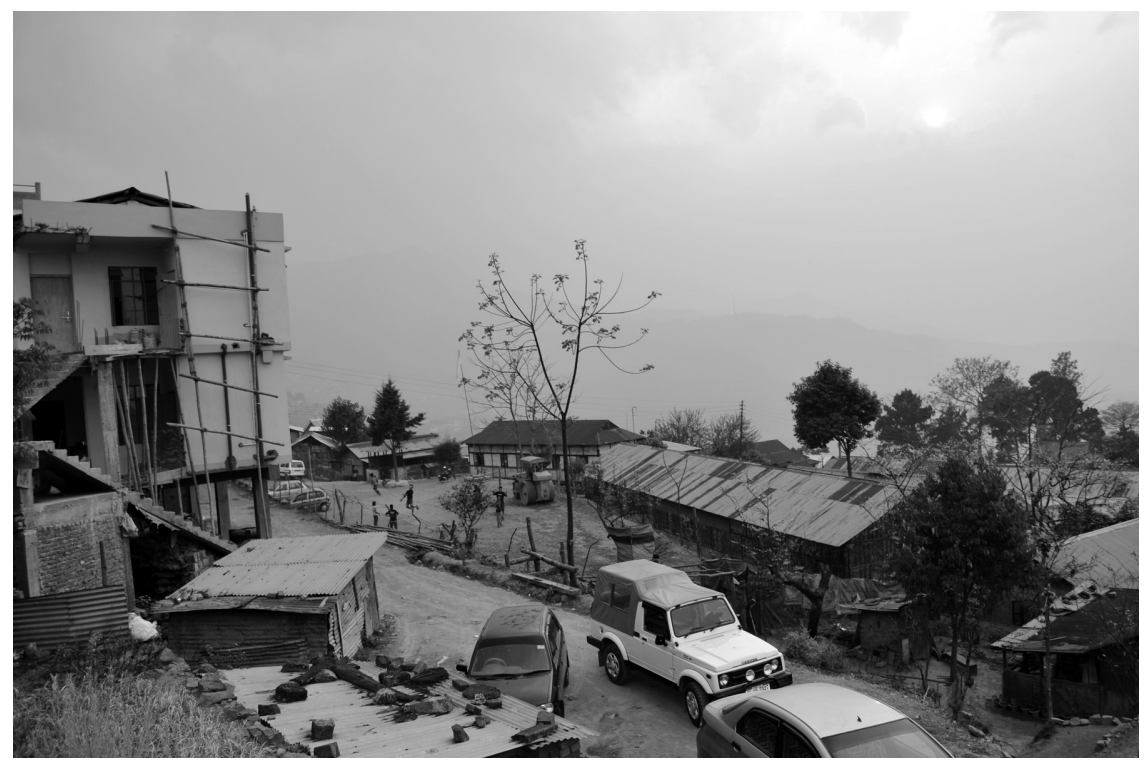

FIGURE 3.1 Naga National Council (NNC) Transit Peace Camp, Kohima.

Source: Michael Heneise, used with permission. 


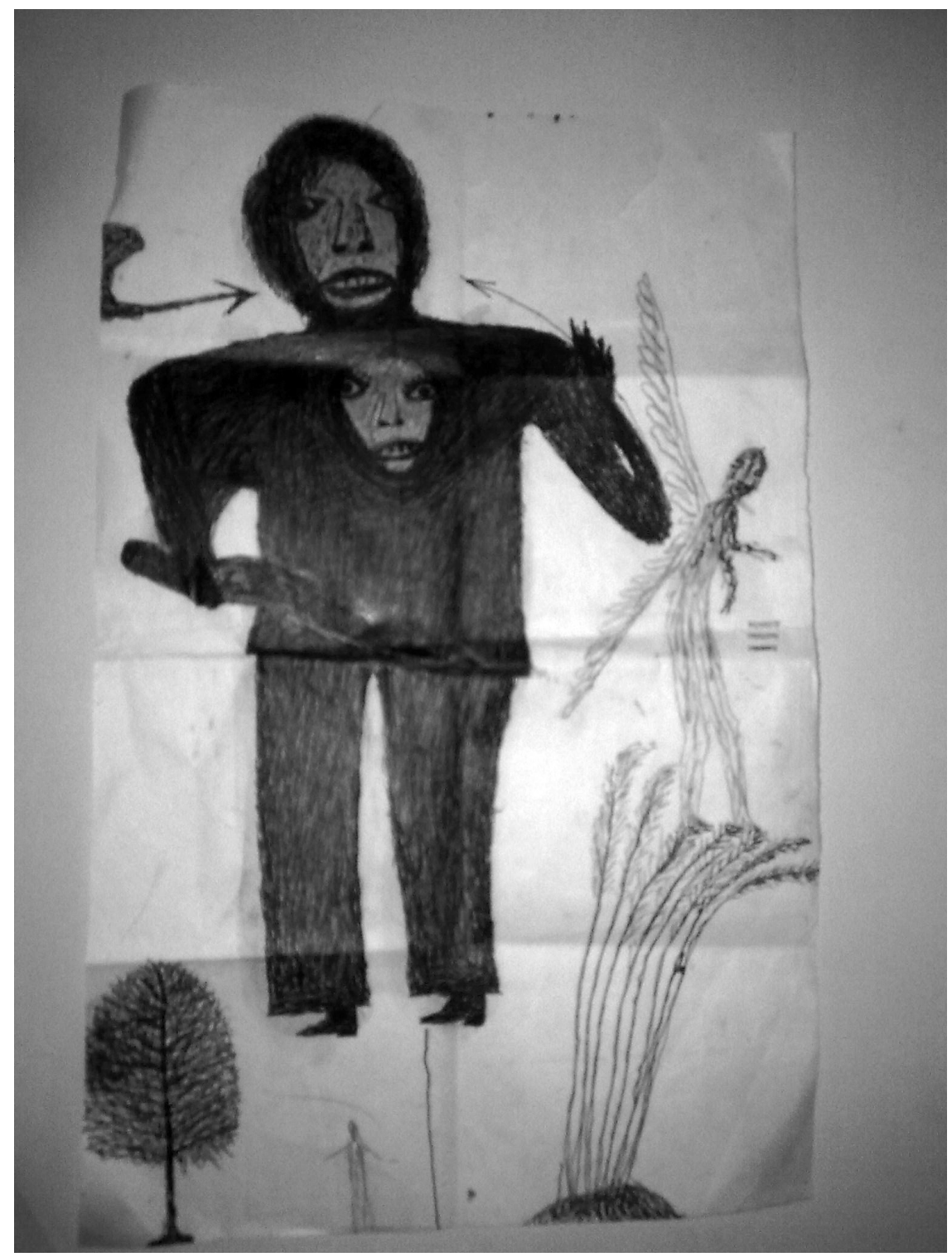

FIGURE 3.2 Drawing provided by the chaplain, NNC camp, Kohima.

Source: Michael Heneise, used with permission.

bloodshed to Kohima. The angel is turning away because of his displeasure towards man. We have to cleanse ourselves and find our true national future; once we have achieved that, then, death will pass. I was also given a Bible verse for you, read Isaiah 40: 31 . 
The NNC Speaker reaches out for a Bible near the desk and reads it: "But those who hope in the Lord will renew their strength. They will soar on wings like eagles; they will run and not grow weary, they will walk and not be faint".

This meeting with the chaplain was rather downbeat given its focus on his vision of the need for the Naga nation to be pure and cleansed if the goal of nationhood is to be fully realised (also Longkumer 2018). But there was also hope in the Bible passage that the speaker read - a hope that depends on the renewal of the human spirit towards God.

We move through the camp and are introduced to another NNC activist and the media officer and archivist, Akok. Sitting on woven bamboo seats, in the damp sitting room, with only a faint light passing through the tiny window, Akok tells me of his ordeals in the Naga army in the 1950s and '60s. Despite the death of many of his friends due to lack of food and disease, like many of the NNC cadres who survived the brutal conditions of the jungle, he emphasises that the "only strength we had was our faith in God" (interview, Kohima, 5.9.14). Even though the numbers were depleted and energy sapped, they would go hunting for wild pigs, deer, and even monkeys, and Akok says, it was as if the sound of their guns were muffled through the thicket of the forest and the density of the air. "Imagine if the Indian army heard the gunshots", remarked Akok. "These small acts were due to God's hand. We would eat these animals and regain our strength to fight for our nation" (interview, Kohima, 5.9.14). The NNC were guided by Christian chaplains, who were also visionaries and dream interpreters.

Dream interpreters played a very important role in our movements in the jungle. "Let's move from this place, I've had a bad dream", and we would be saved. For instance, we would establish a new camp without food, but that's fine, as long as we pray before we establish our camp. But sometimes someone would have a bad dream, and in the dream satan would be chasing the person. So one of the interpreters would say, "let's leave immediately". Then, we would find another camp. And then, we would hear that our previous camp was surrounded by the Indian forces. But it was empty, and we were saved, thanks be to God!

(Akok, interview, Kohima, 5.9.14)

Around the year 1952, during a meeting in the Wokha area of the NNC, instead of calling it the 'Naga hills', they decided to refer to it as 'Nagaland'. "As an NNC youth activist, we wanted to legitimise the idea of 'Nagaland":

We [the NNC youth] would write a letter and on the envelope we would write 'Ms Imtila Naga', and underneath that 'Nagaland' and would post it into the post office without a stamp. 
Akok told me that without a stamp, they knew that it would not get anywhere, but they continued the practice of naming 'Nagaland' - to bring it into being. On one occasion, Akok recalls that he was posting a letter with 'Nagaland' on it and was caught by the postmaster - a non-Naga Bengali man - who asked him to read the address to him. Akok politely read 'Nagaland'. The postmaster questioned Akok and emphasised that 'Nagaland' did not exist and that these letters were a nuisance because they were clogging up the post box and also wasting his time. "Who told you to say "Nagaland", asked the postmaster. Akok replied, "the NNC":

The letters didn't go anywhere. We knew that they wouldn't get anywhere but we were hopeful that the letters would be delivered to the people it was addressed to with 'Nagaland' written on it. We were following Phizo's idea of 'Nagaland' that he envisioned as a 'country'. This was a time when statehood was not even discussed and people had no idea about 'statehood'. At that time, Phizo would write 'Nagaland' in all his letters and even Nehru did not object to it. So it happened like that.

(interview, Kohima, 5.9.14)

The incredulity of the postmaster is not surprising; he could not recognise 'Nagaland' as a legitimate place that could be fixed. For him, the address did not exist. Yet, in the minds of the NNC youth and the cadres, 'Nagaland' was not an exercise in their imagination, but a place brought forth through writing, the letters becoming an important part of a process of place-making. Later, I would learn of the Federal Government of Nagaland's own attempt at making place (Figures 3.3 and 3.4).

\section{Vignette 3: national prayer centre}

Driving southeast towards the Manipur border there is a little known village, Kütsapomi, in the Phek district of Nagaland. It is a small village and one of the last villages to accept Christianity in a predominantly Christian state. Although Christianity arrived in Kütsapomi in 1948, the spread was slow. Even up to the 1990s, when Christianity had entrenched itself fully in many parts of Nagaland, in Kütsapomi village only 30\% of the population was Christian. In 1991, something dramatic happened that saw an increase in Christian numbers. It was down to one man and the Shisa Hoho, a national prayer house (Figure 3.5).

Chosayi Lohe, the main figure behind the Shisa Hoho, is a shy 61-year-old man, and very much a 'village man'. He would not even have ventured out of his village to do God's work, he tells me, until God made it rain relentlessly for two months. Once he left the village gate, it stopped raining. He was still reluctant, and his tussle with God continued. One day God told him to cease working in the fields and to work for God instead. But as a farmer, with a family that depended on the harvest from the fields, he was hesitant. "How can I feed my 


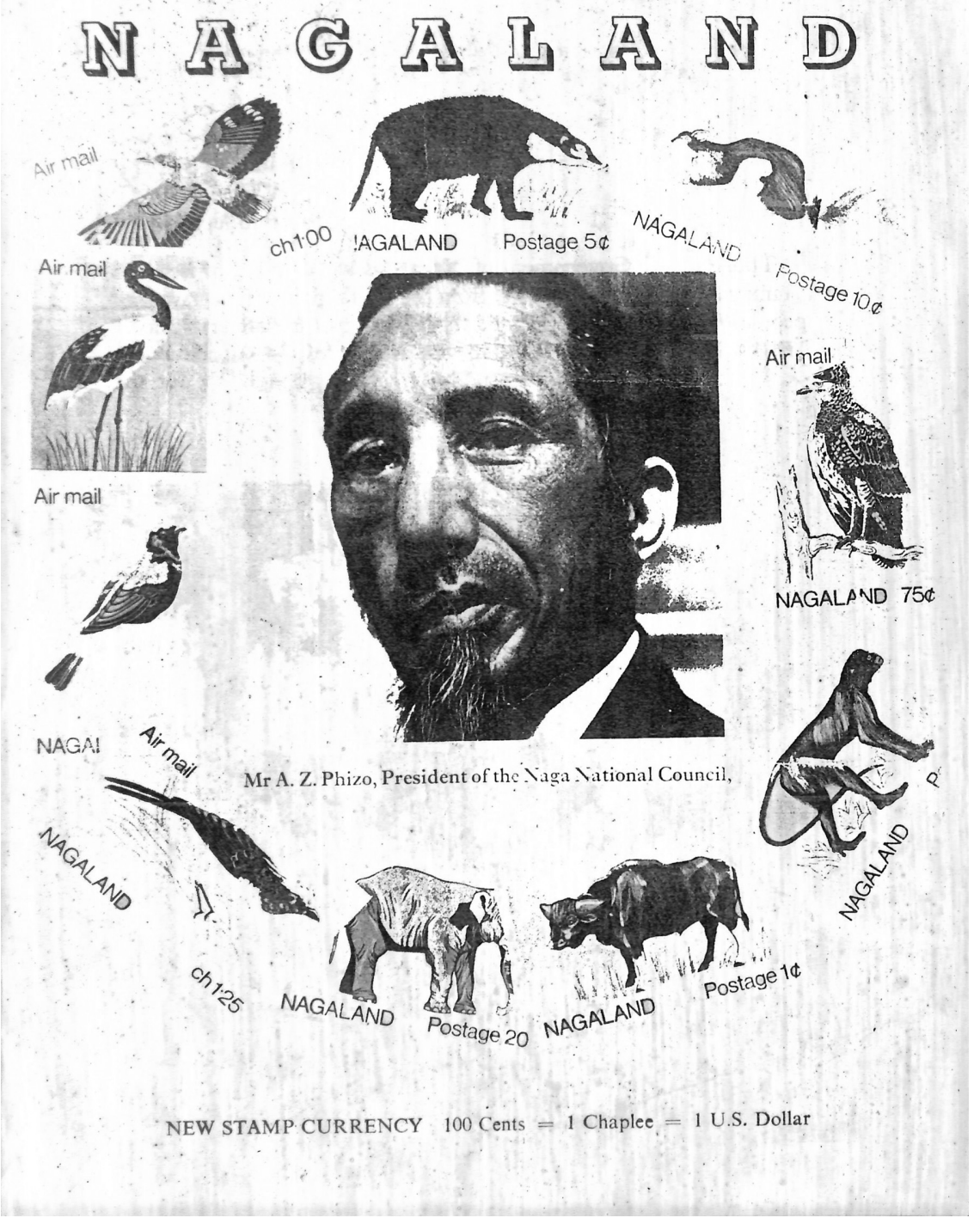

FIGURE 3.3 NNC stamps of Nagaland.

Source: Naga Archive \& Research Centre, used with permission.

family if I don't work", Chosayi replied to God's interdict. Desperate to continue ploughing the fields, he took his spade and went to his agricultural field. When he reached it, the field was covered in earthworms. No one could work. Partly amazed by this occurrence but also filled with doubt about God's command, 


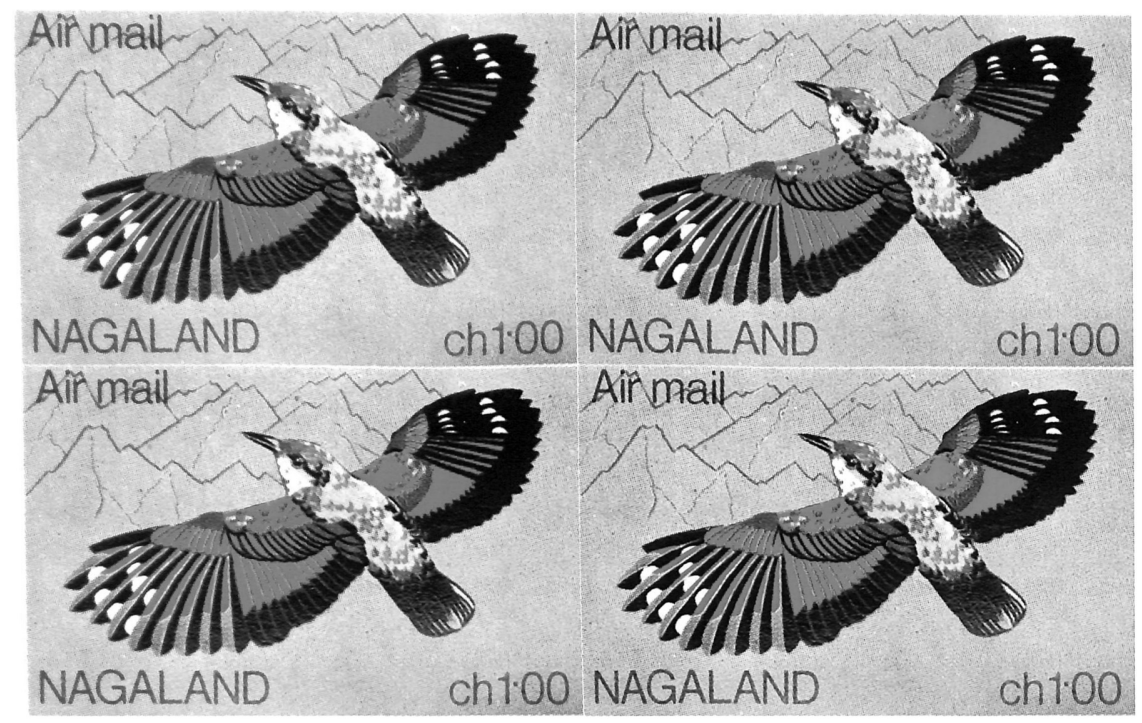

On 22 $2^{\text {nd }}$ March 1956

The Federal Government of Nagaland decided to issue its own stamps as not only a necessity from the postal point of view, so that the people of Nagaland can be sure that their mail is delivered and is safe in the hands of its own nation, but also to let the outside world know that Nagaland is an independent government fighting for the survival of the Naga people.

FIGURE 3.4 NNC stamps of Nagaland.

Source: Naga Archive \& Research Centre, used with permission.

he went back to the village to continue his daily chores. Upon picking up his children's clothes to wash, lice gathered and multiplied all over them. He managed to boil some water quickly and put the clothes in hot water to kill off the lice. Chosayi was tired and angry at these occurrences. God then spoke to him, and he tells me that the memory of it is as clear as day: "If you don't obey my 


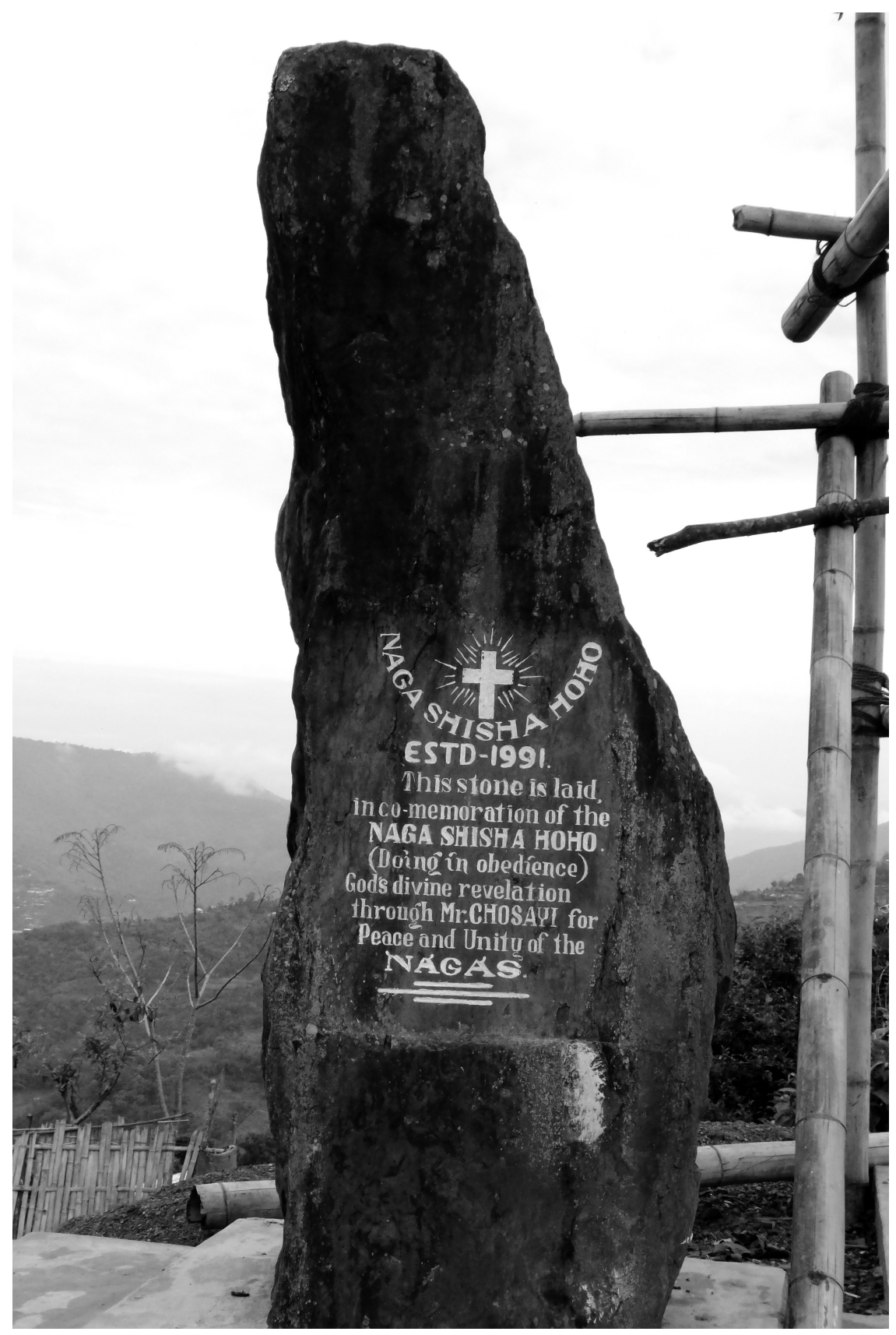

FIGURE 3.5 Naga Shisha Hoho Monolith, Kütsapomi.

Source: Arkotong Longkumer. 
commands, these things will keep happening". There and then he surrendered to God. Until today he remains faithful to God, he tells me. Unable to read and write, Chosayi hears God's words in dreams and through speaking in tongues in prayer, sometimes undecipherable even to himself. But with time the meaning becomes clear. Through these media, God communicates with him (interview, Kütsapomi, 24.4.15).

'Shisa' means 'doing in obedience', while 'Hoho' is a word representing an organisation. No one can trace the word - Shisa - to any of the tribal tongues spoken in Nagaland, and some of the villagers think it is 'in spiritual tongue'. Chosayi is also unsure of its origin - but affirms the villagers' interpretation. The main task of Shisa Hoho, he tells me, is to pray for Naga sovereignty. According to Chosayi he had a vision in 1990 that the Naga plebiscite of 1951 was the beginning of Naga nationalism and will be the end - "the first mandate shall be the last". ${ }^{5}$ In fact, according to the history of the village, the unity of the Nagas relates directly to the village unity. The first act of unity was in 1962. An NNC military camp was set up called 'Happy Camp' in Kütsapomi.

The 9th Tatar Hoho (or Assembly) was held in March-April 1964 at Happy Camp to deliberate on whether the NNC, on behalf of the Nagas, should sign a bilateral ceasefire with the Government of India (the first Indo-Naga ceasefire was subsequently signed in September 1964). As a celebration of this moment, Kütsapomi offered 44 caskets of paddy, mithuns, and pigs to the meeting of nearly 700 delegates ranging from both the Naga military and civil society. After almost three decades, and a series of factional conflicts and fragments amongst the Nagas themselves, Chosayi remembers God's voice again: "Unless Nagas come together, there will be no sovereignty". But Chosayi was unsure how to put this into practice. God then instructed him to go to the various nationalist leaders and "say to the leaders that they must stop killing each other". Sitting in front of the Naga Shisa Hoho flag whose colours and patterns he saw in a vision, closely resembling the Naga national flag, he tells me that the main prophecy of the Shisa Hoho is for Naga unity. He explains:

Whenever I meet any group, God reveals the same message. You have to come together. There's only one sovereignty, and there can't be more than one. Only after you come together, God will elect a leader.

(interview, Kütsapomi, 24.4.15)

Although Chosayi had no background in dealing with nationalist leaders, God directed him to speak. Some believed, while others doubted Chosayi's intentions. Violence continued amongst the various factions, but eventually they realised the futility of it and people started to believe in Chosayi. Chosayi's role as God's emissary allows him to travel to different locations. Not only has he relayed God's message to nationalist leaders such as Isak and Muivah of the NSCN-IM, but he has also travelled to Burma to meet Khaplang of the NSCNK. It took him two days on foot, two days by boat, and two days on a bike to 
reach Khaplang's headquarters in Western Myanmar. He has also undertaken a pilgrimage to Jerusalem and Bethlehem for three days organised by the Naga Baptist Church Council (NBCC). The beauty of the Naga areas, he says, cannot be compared even to the glory of Jerusalem!

One must remember the difficult context of this mission thrust upon Chosayi. In the late 1980s and early 1990s, factional violence between the NSCN-K/IM and the NNC was at its height, remembers Chosayi. The villagers in particular were affected by these events, as they had no strong institutional and state protection like those in the urban areas. As a response to God's message of unity in 1991 and 1993, the Shisa Hoho organised large gatherings in Kütsapomi village. The event in 1991 was primarily for the village as a form of internal unity and purification to prepare themselves for the larger 1993 event when they invited hundreds of Nagas from all over the region.

Another prayer warrior (Figure 3.6) associated with Shisa Hoho, Vechilu Rhakho, recalls the situation. During the village gathering for Naga unity in 1991, Christian revivals also 'spread like wild fire': 1991 was a watershed moment in Kütsapomi history; in 1989 a woman had prophesised that the village would become the main organisation to work for Naga unity (realised in the Shisa Hoho) - that "your language, your water, your source of vegetable will enhance your village" (interview, Kütsapomi, 24.4.15). It was not clear until the events in 1991 and 1993 for unity happened that reminded them of the connection with the 1989 prophecy. Water (in the form of rain) sufficiently watered the fields, and food production multiplied during this time so that a small village could

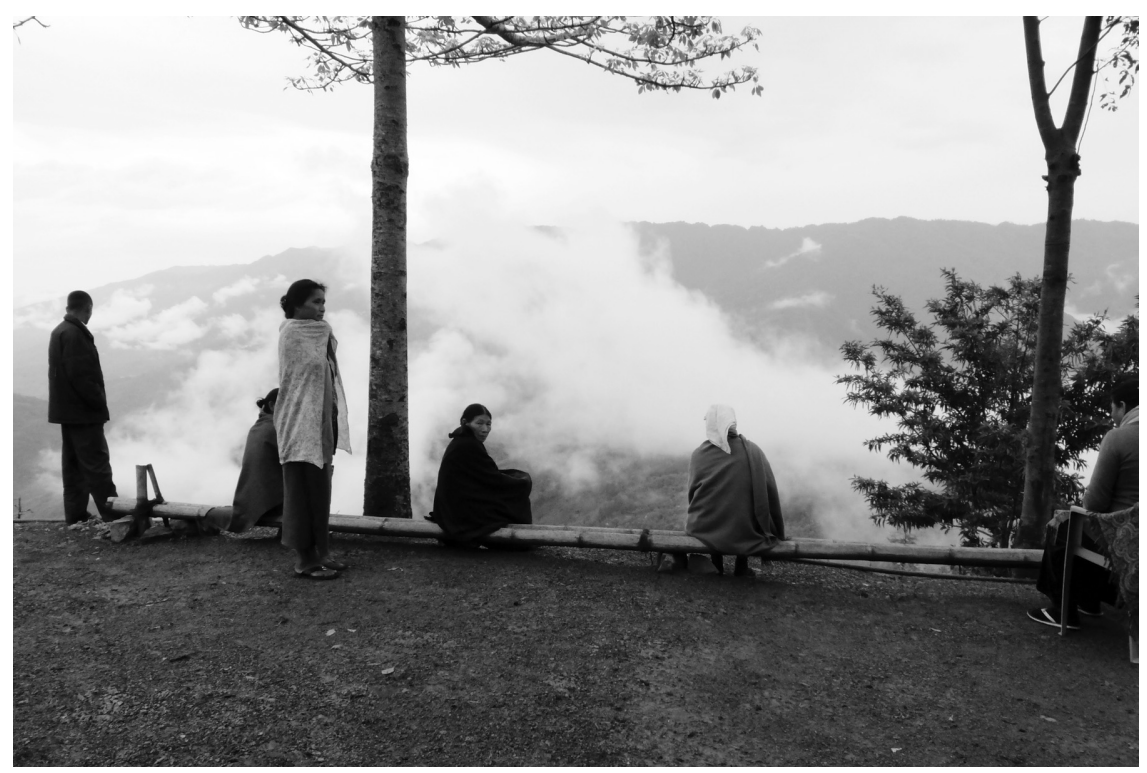

FIGURE 3.6 Women Prayer Warriors that Rhakho is a part of. 
host such large events. The language of communication in the village - Sumi, Chokri, and Kheza (the main languages of the Chakhesang tribe) alongside Nagamese and some English - allowed them to reach out to diverse audiences across the Naga areas, particularly during the two events.

Prophesies about the Naga nation, alongside healing and a new feeling of solidarity and revitalisation amongst the villagers, developed during this time. "With Christianity", argues Vechilu, "came a clearer vision of the Naga nation" (interview, Kütsapomi, 24.4.15). Drawing a clear division between their preChristian past, and their present Christian identity, Vechilu suggests that Christianity "brought about a moral awakening which was different from 'traditional society"” (interview, Kütsapomi, 24.4.15). For Vechilu, Christianity's association with modernity (schools, jobs) brought about a clearer vision of the future. A plaque commemorating Phizo's visit in 1952 represents a prophecy, perhaps, of what was to come in Kütsapomi in 1991 (Figure 3.7).

To say that the history of the village is intimately tied to the Naga nation is an unquestionable fact, according to the Shisa Hoho. This is how Vechilu justifies the connection:

Two very important prophecies are these. [1] God really wants the Nagas to come together. [2] Naga sovereignty is not being sought under the Indian government, but if we come together the UNO (United Nations Organisations) - and those who have big nations, they will support the Nagas. So it will not be under the Indian government. But it will be under world organisations or that world organisations will decide Naga sovereignty.

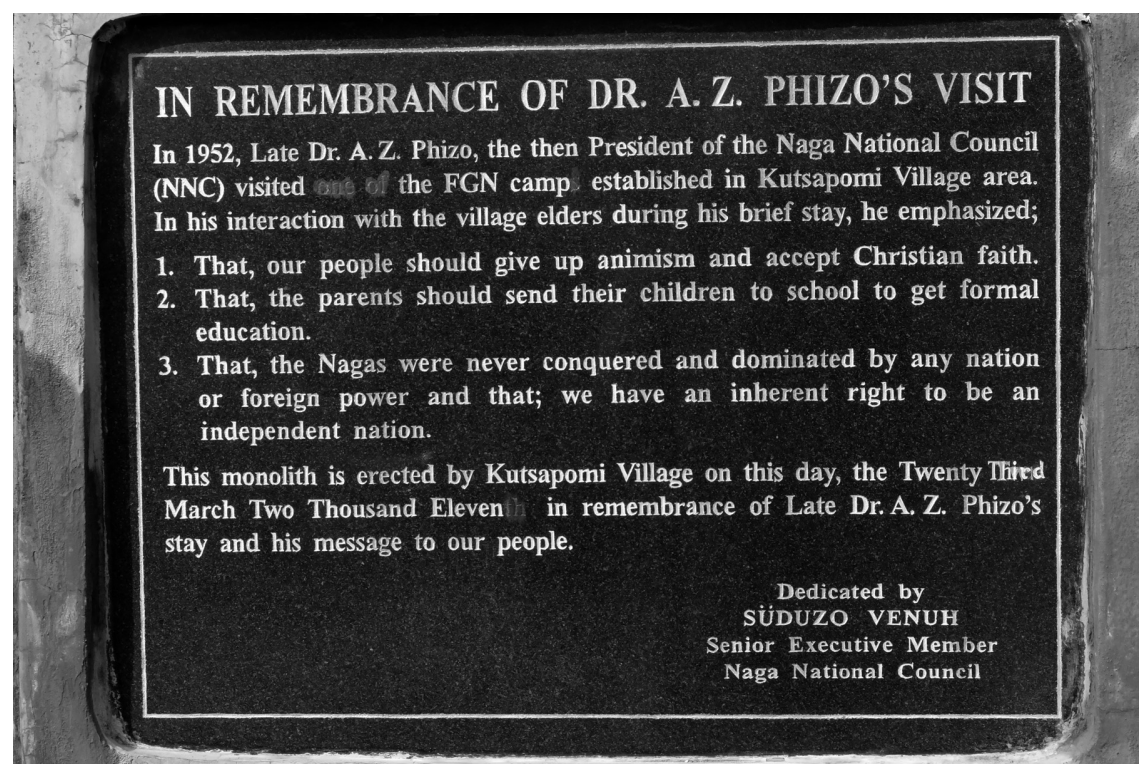

FIGURE 3.7 Plaque commemorating Phizo's visit.

Source: Arkotong Longkumer 
So at noon we pray for the world organisation to deliberate on Naga sovereignty. Though you can't always contribute to Naga sovereignty through your knowledge, we always pray for the leaders of the world powers to grant Naga sovereignty. And this noon prayer is done every day.

(interview, Kütsapomi, 24.4.15)

\section{Ecology of practices}

Sovereignty as a set of practices is spun out of the tangled web of history. For many of the human actors concerned, whose sole purpose has been to preserve the workings of what it means to belong in a landscape shared with their ancestors, spirits, and deities, it is non-negotiable. These practices are embedded in what David Anderson (2000), in his work on the relationship between animals and their environments in Arctic Siberia, calls 'sentient ecology'. Drawing on Anderson's idea of sentient ecology, Tim Ingold suggests that another word for showing sensitivity and responsiveness to this relationship is intuition (2000: 25). This landscape sociality that both Anderson and Ingold evoke suggests a kind of knowledge that is:

not of a formal, authorised kind, transmissible in contexts outside those of its practical application. On the contrary, it is based in feeling, consisting in the skills, sensitivities and orientations that have developed through long experience of conducting one's life in a particular environment.

(Ingold 2000: 25)

Ingold, particularly, questions the kind of 'sovereign perspective of abstract reason' (2000: 25), but rather calls us to value the perspective and skills cultivated, embedded within this landscape sociality, akin to a 'poetics of dwelling' (2000: 26).

Chungshi, the elderly NNC man, recalls his contribution to the Naga cause for sovereignty in the early years of the NNC - the crushing of his jaw by boots and the pain he feels are a constant memory. His role as a shaman allowed him to read signs through a sense of awareness of the natural surroundings and how they guided him and his troops away from danger. The foresight and vision of an arasentzur and a Christian man enabled him to forge paths in his fight towards freedom from hegemony, and protecting his soldiers from harm, are in so many words about being sovereign - unencumbered by 'foreign forces' wishing to dominate and rule. Now he spends his time in a prayer centre, praying for the sins of the national workers, so that they may be forgiven and revived as they continue the fight for sovereignty.

Akok's commitment to sovereignty finds him sequestered in the Transit Peace Camp. Although maintaining the ideology of the NNC, now their path is no longer violence but peace. They fight their battles through words, preserving and archiving the memory of the national struggle, and passing on their knowledge to the younger generation so that they will remember the sacrifice and honour of their ancestors. 'Naga-land' for Akok, even before it was, existed through 
the writing of letters that questioned the time-space of addresses and in the process enforced a will. Although it might be a stretch to suggest that Akok and his NNC youth friends' intervention brought about the naming of 'Nagaland', it should not surprise us that for Akok and his friends, they believe they shared in the naming of the 'land'. These names and the accompanying paraphernalia of NNC flags, and stamps, are not only symbols for internal consumption but are also about external recognition, mimicking the way nation-states function, and in a way legitimising their place in the world of global politics. Sovereignty here is both a process of place-making and a "universe of objects and events", as placeworlds, where particular ideas are brought into being (Basso 1996: 6). There are two aspects here noteworthy for examination that are nourished by ideas of place-making and through acts of naming that are, as Paul Carter observes, paradigmatically an act of possession and making it one's own: "By the act of place-naming, space is transformed symbolically into a place, that is, a space with a history" (Carter 1987: xxiv). This 'space with a history' is brought to life through the process of naming 'Nagaland'.

For Chosayi and the Shisha Hoho, unity, peace, and solidarity are the ingredients to achieve sovereignty, though very much based on a male gaze. This gendered-ness of nationalism is very much visible in the power of men who lead, decide, and dictate the direction of the Naga nation. Chosayi and the Shisha Hoho view the historical archive of the Naga struggle from the vantage point of the present without ever dismissing what came before, forging a path towards the future, though inhabited by the plebiscite of 1951, an event that is "now as ever", as Chosayi told me (interview, Kütsapomi, 24.4.15). While obedience and surrender to God's will is characterised by Chosayi's commitment, so too is this about the story of the village, Kütsapomi. Its smallness with its abundance in food, water, and the diverse languages spoken makes it an ideal place to fight for Naga unity, always revitalising and reactivating the 'essence' of Naga sovereignty. Only when obedience is cultivated, then, will sovereignty come, they say. But such a mode of sovereignty also exceeds the nation-state. For the women prayer warriors like Vechilu, Christianity brings clarity to their struggle for indigenous peoples' rights that will be brought to the attention of the U.N. Not the Indian state, but the U.N. will support the Nagas in their fight for their right to self-determination. The method that elevates these concerns purely from the local - such as the stories that I have narrated - to the global are the interventions such as those by Vechilu. The ritual prayer at noon for 'world leaders' to solve the Naga issue, and for those prayer warriors to be open to the presence of God, simultaneously speak about grace, and witnessing a new state of being.

Jiribam represents the dark side of nationalism; it reminds me of unattained dreams and violence, but also that, somehow, hope remains undiminished. Ghatashi and the prophecy of me arriving in the morning sun happened for the very reason that my time, like the time of all those invested in the nation, is intimately enfolded with people, events, and visions from God. How do we develop an analytical tool to probe the workings of the cosmos? Can a 'common world' 
populated by different entities be treated as historical cause? It may require that the usual historical methods be suspended, and a space of indigenous sovereignties cultivated.

\section{The global situation}

It was a cold and bright February morning in Karasjok in Finnmark, Northern Norway in 2018. Along with friends and colleagues Siv Ellen Kraft and Bjørn Ola Tafjord, we arrived at the Sámediggi (or Sámi Parliament) to learn about the building, the history, and its place within the Norwegian nation-state, but also to understand the complex algorithms of how it stands in relation to the other Sámi Parliaments in Sweden and Finland (and the Kola Sámi Assembly in Russia). What was largely planned as an informal tour of the Sámediggi turned out to be a surprise, serendipitous to say the least. As we were milling around the reception desk and trying to register our names for a tour on the automated machine, unsure if there were any guides to take us around, a man behind the reception desk asked Siv Ellen where her colleague (nodding towards me) was from. When Siv Ellen said "Nagaland", his face immediately lit up, and he walked over from the reception desk and introduced himself as Anders Henriksen. He immediately said that we were his guests and he would take us around.

Anders Henriksen is the Communications Manager of the Sámediggi, and during our conversations he explained that he built a close relationship with the Nagas through his association with the Sámi artist Hans Ragner Mathisen ('Keviselie') and Visier Sanyü, an Angami Naga from Nagaland. In the wake of the Vietnam War in 1974 and sparked by a vision of a "new Asia and a new world" (Sanyü and Broome 2018: 128), a group of young students embarked on a world tour with the musical 'Song of Asia'. It was an opportunity to present "a case for peace in Asia through music, dance and drama" (Sanyü and Broome 2018: 128). Among them was Visier Sanyü. The tour proved life changing, connecting him with several people, one of whom was a young Sámi art-student Hans Ragnar Mathisen during the 'Song of Asia' performance in Oslo in 1974. Since then (1976-present) they have been writing letters and have developed a friendship across national borders that speaks of their common understanding of indigenous peoples' rights and their place in their world.

Anders Henriksen showed us a photograph of various indigenous activists from all over the world taken in 1990 during the World Council of Indigenous Peoples organised in Tromsø, Norway (Figure 3.8).

Henriksen is also part of the Sámi Naga Friendship Association (SNFA) founded by Visier Sanyü and Hans Ragnar Mathisen, and they regularly organise events on Naga Independence Day on the 14th August. For example, during Nana: International Festival of Indigenous Culture in Tromsø (7-17 August 1997), the 14th August was scheduled as 'Nagaland Day' and Visier Sanyü of the SNFA listed as the main speaker. But Nana is not the only moment in which the Sámis and the Nagas, along with other indigenous communities, have interacted. 


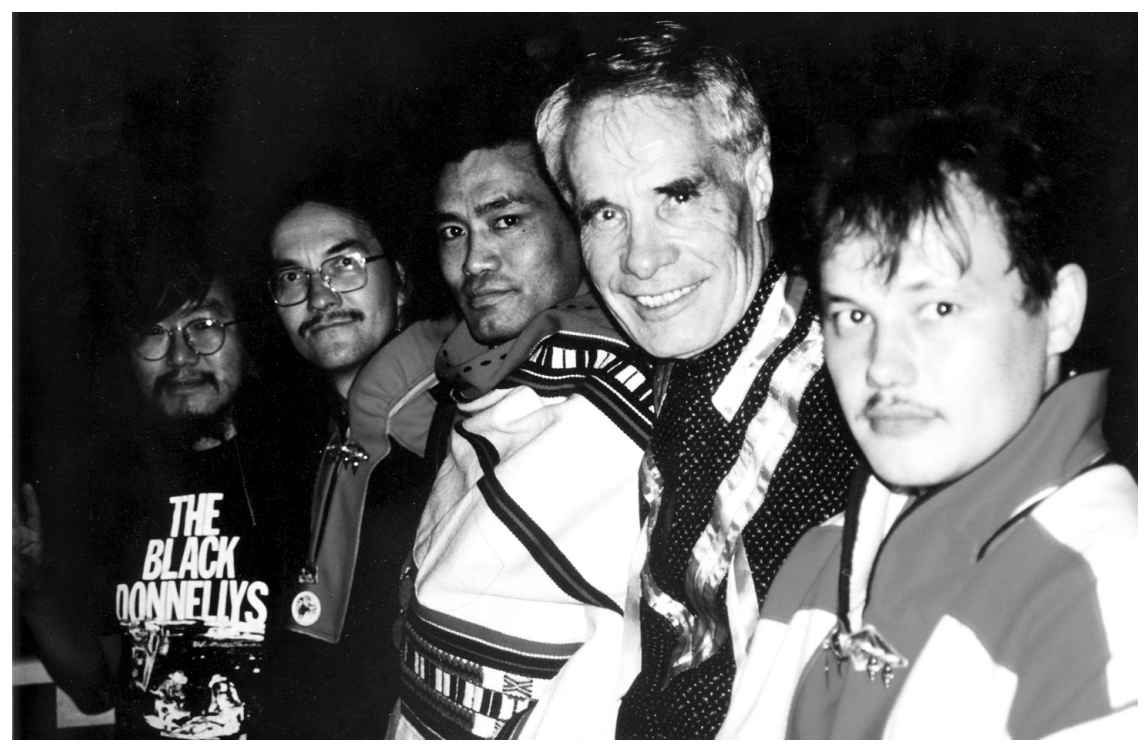

FIGURE 3.8 From right to left: Anders Henriksen (Sámi), Grey Eagle (Native American), Visier Sanyü (Naga), Hans Ragnar Mathisen (Sámi), and Alooktook Ipellie (Inuk).

Source: Used with permission from Hans Ragnar Mathisen.

In 1984, an event called Indigenous Days organised by Hans Ragnar Mathisen in Tromsø brought together participants from Nagaland, Canada, Kalaallit Nunaat (Greenland), and the Sápmi.

I relay these stories and events in order to acknowledge the global reach of indigenous politics but also to affirm the importance of scales and encounters, which may not always correspond with our notions of how indigeneity are circulated and affirmed. The idea of 'indigenous friendships' is an excellent example of how it crosses continents and contexts, with its abiding concern for solidarity and 'cultural intimacy' (Herzfeld 1997). These moments of 'intimacy' do not occur in the institutional corridors of power, nor in the networks that air complicated grievances of cultural and national rights, but in moments of 'common sociality' - through letters, words, art, memoirs, song, ceremonies, and memories that speak to the domain of human life and its infinite possibilities. It is in tracing these intimate archives, I suggest, that the social biography of power lies and the capacity to cultivate friendships - against all odds - over the longue durée and over vast stretches of land.

Friendships, connections, networks, festivals, solidarity, and protest movements (see various chapters of this book) are where the shared aspirations of indigenous peoples provide colours beyond the usual striking hues and produce resonances that are primarily beyond the 'local' or the 'official'. It is also in the space of friendships, where there is, as Paul Rabinow explains, "a primary 
site of thinking" that enables people "both to think and to act" (1996: 13-14). The result of having friends and cultivating a sense of curiosity for and activities with other peoples is to inhabit a cosmopolitan attitude that transcends normal geographical barriers. It is in these encounters of dwelling, I argue, where its potential has political effects that are not only real, but actualised in the world. These ideas also correspond with Anna Tsing's argument, drawing from Annelise Riles' (2000) work, to take 'networks' seriously - not as naïve or simple formulations of rhetoric, but a coming together of "webs of imagined interconnection through which groups in one area were to exchange information and support with other groups on what was seen as an egalitarian, voluntary basis" (Tsing 2000: 335). Indeed, one can see through this an emergent process of 'future globalism' in which networks, rather than "nations and bureaucracies . . . will be the organising aesthetic" (Tsing 2000: 335).

The INREL project, out of which this book emerges, is very much situated in what these networks are and how they are imagined in scales - in their geographical and transnational lift - but also in the ways they provide the different research interlocutors of interconnecting with ideas of circulation, flows, linkages, and 'scapes' (Sassen 1998; Appadurai 1996; Harvey 1989; Kearney 1995). Such words are not invoked simply in order to capture the global zeitgeist of scholarly fashions; rather, this chapter, like the book itself, has in mind the specific instances through which the complex interplay of media, popular culture, travel, social movements, and national visions, come together through 'sites'. It is in the midst of these global circulations - travelling through four continents, searching through online booking sites, cooking and ordering food and feasting with friends, queuing through immigration, losing luggage, exchanging currency, dealing with exhaustion and jetlag, and feeling the excitement of visiting new places - that key ideas of INREL surrounding sovereignty, performance, translation, media, and comparison were remade. This global epoch of intensified circulations is something that scholars of globalisation have all observed (Hannerz 1989; Kearney 1995; Tsing 2000; Appadurai 1996; Clifford 1997). But what did these experiences bring to this chapter specifically?

Certainly, this chapter is a reflection on what I call sovereignty in motion as I encountered different notions of how it is articulated, acknowledged, and lived, sometimes without the excessive and hyper-political realities that often accompany expressions of sovereignty. Tellingly, ideas of sovereignty that were lodged in my thinking as involving only certain forms (like territorial independence) gave way to broader and more innovative ideas about sovereignty. And, in the following few paragraphs I give a sense of how these encounters may inform and equally may be informed by this idea of sovereignty in motion.

\section{Sovereignty in motion}

As members of the INREL team travelled to Nagaland, they were struck by open expressions of sovereignty that perhaps I took for granted. En route to the famous village of Khonoma, just west of the state capital, Kohima, as we 
navigated through the winding and dusty roads, we stopped at a famous monolith that read "Nagas are not Indians; their territory is not a part of the Indian Union. We shall uphold and defend this unique truth at all cost and always". These words are attributed to Khrisanisa Seyie in 1959, the first President of the Federal Government of Nagaland. Out came the cameras and phones; Greg Johnson, the Hawaiian expert, quickly uploaded the image onto Facebook and circulated it with the phrase "hey Hawaiian friends, check this out from India. Hardcore sovereignty". This is followed by "Hardcore Sovereignty 2"; Johnson uploads an image of a monolith with these words etched onto it: "In Memory of Viyalhu Zhünyü by his Grandsons. Brutally beaten up by the Indian Army in 1956 because he said: 'At any rate the Nagas can never accept anything less than the Naga sovereignty"'. Underneath the image is Johnson's comment: "Check this out [specific Hawaiian activists are referred to] the indigenous Naga are super intense about their sov".

'Likes' from all over the Hawaiian and Native American worlds, including friends and family, are made visible through Facebook, circulated and distributed in time and space, highlighting new encounters. Here Facebook and the Internet are powerful sites to generate symbolic and cultural capital (Ferguson and Gupta 2002). They organise the practice of sovereignty as an affective political site around images and their meanings because these images and words are visible in public spaces; politics then takes the form of a "cultural regulation of publicity" (Cody 2011: 45). The practice of sovereignty through these media technologies spread as 'polymedia' (Madianou and Miller 2012) that find their way into numerous other avenues like books, clothes, posters, and public spaces that other chapters in this book also explore.

I refer to these instances specifically because I too was intrigued about what my friends and colleagues thought of these expressions of sovereignty. They were surprised, for instance, that the Nagas owned their lands through customary law that the Indian state recognised, unlike other native peoples in North America, for example, where most lands are part of the state. What was a takenfor-granted practice amongst the Nagas, then, was elevated into a comparative project of how and what sovereignty entails in the global ecumene of practices and traditions that were distinct but yet made comprehensible due to encounters, visitations, and experiences in different research sites.

We drive from the eastern coastal town of Puerto Viejo in Talamanca, Costa Rica. Beaches, resorts, surfers, tourists, and balmy evenings with cocktails are left behind as we drive northwest towards our destination, Sibudi, a Bribri village. We stop at a little trading town, Bribri, for nourishment - the scene, the people, and the landscape change. Suddenly, the smooth tarred road gives way to a rough, rugged one. The transition, like a crossing, brings up questions about development, state-making, and resistance. Fresh from reading James C. Scott's book The Art of Not Being Governed (2009), a book that has been central to my thinking about Highland Asia, ideas of state-evading, deliberate choice making, and the ability of indigenous people to resist the machinations of the nation-state, 
are corporealised through travel in Talamanca. In Nagaland, where all roads are rough and where issues of development are central to the national discourse of progress, here I was struck by the deliberate strategy and agency of the Bribri of resisting development (even when smooth roads could be had) and thus the reach of the state. The buck does not stop at the road.

The river Telire provides another crossing as we take a rickety old wooden boat from Suretka upstream west towards our destination. We land in Sepecue, a place where the boat moors and a bus arrives, taking passengers from the bank of the river inland towards the Bribri villages. The scene becomes familiar now. It reminds me of Naga villages, the waiting for the bus, the dense tropical jungles, the rain, the damp, the sound of insects, the moisture in the air after torrid monsoon rains. Our hosts Yari García and Elías Escalante welcome us, nourish us, shelter us, and speak to us about their lives in Sibudi. I notice the electric lines crisscrossing the village and question our hosts about the lack of electricity in their home - both were adamant and even convinced that this is a choice that they have consciously deliberated on to negotiate change their way. I thought about remote Naga villages where electricity was still a dream, an anticipation, a future globalism, and the sacrifices they would make to engineer connectivity. Yet, here, in Scott's anarchic mode, the idea of agency and resisting desires for expediency, access, and connectivity that everybody 'must have', gives way to resistance. These acts of resistance are a powerful reminder of the way sovereignties play out on different levels and scales. I suspect these revolutions are not simply about rejecting these alluring forms; they are alternative ways of dwelling and a way to staying 'in our own time'.

Hawai' $i$ too challenged me in different ways to think about sovereignty, or high altitude sovereignty. The mountain Mauna Kea, standing at around 13,800 feet, looms large in the landscape of Hawai'i Island, in Hāmākua Coast, Kohala, and Mauna Kea regions. At the centre of sovereignty for me was what Mauna Kea signifies in light of indigenous futures. Hawaiian futures were encapsulated and circumscribed through ideas of sovereignty and sacred claims, or what Pamela Klassen calls "spiritual jurisdictions", where the "metaphysical blend of spiritual and political power materialized in symbols, rituals, and stories" (Klassen 2018: 119; see also Johnson, Chapter 5). The technologies of scientific explorations into space with the proposed building of a Thirty Meter Telescope (TMT) on Mauna Kea, and the resistance involving many native Hawaiian activists, mediators, and interlocutors, bring to the fore complex questions regarding 'future globalisms' for both sides of the TMT debate. Here the register of sovereignty is amplified through shifting categories where protesters become protectors, where European science collides with indigenous knowledge, and where what counts as evidence deeply divides the terrain upon which the future of Mauna Kea are framed. Unlike Nagaland where such sites as focal points of struggle like Mauna Kea are absent, and where the language of 'spirituality' and 'sacred claims' are marked departures from Hawai' $i$, what was distinctly similar were questions regarding indigenous futures couched in the language of sovereignty, identity, 
language, and claims over land. Through these insights, otherwise impossible if not for this project, my own thinking about sovereignty was lifted from tired old demonstrations of political slogans. I began to understand the freighted, creative, pragmatic, inspirational, and indeed worthwhile task of thinking about sovereignty through routes taken - Sápmi, Talamanca, Mauna Kea - through the corridors of international academic conferences, special issues, edited books, and conversations over tables, chairs, and seats in workshops, cars, airplanes, and over numerous dinners where wine and beer soothed our tired bodies and made way for heady conversations well into the night.

\section{Conclusion}

Sovereignty as practice, an idea, an inspiration, as hope, as futures are entangled in processes and flows around the globe. Sovereignty takes on many forms and acts as a catalyst to engender other forms. It is never static, nor is it always ever complete, but always in the process of becoming. My attempt in this chapter has been to capture some of the moments through which a 'common world' can be envisaged.

Naga sovereignty, understood by its many mediators, is one such example of sovereignty becoming real through the lives of individuals and their relationship to the landscape, place-making, and prophecy that speak of indigenous futures not as a predictive gaze of uncertainty but where distinctions such as the "struggle in the present towards a goal in the future .. . [converge, and where] the struggle and the goal, the real and the ideal, become one in the present" (Maeckelbergh 2009: 66-67; quoted in Lazar 2014: 95). But sovereignty is not simply this worldly in terms of its temporal and existential struggle, but a cosmopolitical one where humans share a 'common world' with gods, deities, spirits, objects, nature, animals, and ancestors that bring complexity to the idea of sovereignty as shared and distributed amongst different entities. At least in the Naga case this comes out clearly; a practice that is embedded within indigenous Christianity, alongside (and sometimes exceeding) concomitant allies in tradition, custom, landscape, dreams, visions, and prophecies. Thus, via Chakrabarty's insistence on taking account of heterogeneity as part of questioning the European diktat on historical thinking and writing, we see the numerous ways in which the Naga archive is populated with instances where God's active involvement in history itself questions the very nature of what constitute 'social facts' as well as how we think about historical cause.

While the Naga case is an instance of indigenous sovereignties, the global situation is inaugurated by numerous encounters that not only give flesh to how sovereignty, as becoming, expands and exceeds the geographical boundaries of the nation-state, but also how it substantiates those relationships through exchange, flows, and travel. The three comparative examples - Sápmi, Talamanca, Hawai'i - are used as an analogue to hone in on larger issues in the chapter but also to acknowledge my debt to these visions in ways that may now 
be already clear. In all these cases, the poetics of dwelling, an idea of Ingold's that I evoked earlier, allows me to observe how encounters, crossings, and flows refract with ideas from Nagaland. In Talamanca, for example, I was struck by the territorial demarcation, perhaps even a physical anarchic space, that spoke of sovereignty through the natural lay of the landscape. The rugged road, the river, the boat, the waiting, the crowded bus, and the choice over to have or not to have electricity provide another analogy of temporal and spatial designs that are counter-intuitive to the neo-liberal time and experience in Puerto Viejo and San José. Perhaps I discovered evidences of Scott's state-evading practices more here than I did in my home turf of Highland Asia. In Hawai' $i$, the high altitude sovereignty, similar to Scott's description of hill nationalisms as evading state-making projects, and where the recalcitrant landscape hinders access, the route up to Mauna Kea in contrast is paved with pristine grit and tar that makes the drive comfortable. But Mauna Kea is also a sentient landscape for many who participate in protecting its presence from defilement and destruction. Again, here, the neo-liberal time of progress as marching to its own rhythm is interrupted by indigenous timescapes that speak to futures and the capacity to engage with different entities, both human and non-human, amidst the periodic booms of the testing of the latest US military bombs heard in the distance. In Sápmi, I discovered friendship, the forging of relations over vast stretches of land, and the ability for indigenous peoples to envision something different, away from the institutional spaces to the more intimate places of sociality. These encounters are about dwelling in spaces that allow for resistance as well as provide a 'method of hope' (Miyazaki 2004). I suggest that it is very important to go beyond the metaphor of 'resistance', because it often implies that people are only responding to the initial and major agency of others (those whose acts are resisted). An emphasis on a 'method of hope' shifts the focus and highlights more of the agency and the ambitions of the people with whom we collaborate. In distinct ways, Nagaland, Talamanca, Hawai'i, and Sápmi encapsulate Appadurai’s eloquent call in his response to Sherry Ortner's (2016) article, Dark anthropology and its others: Theory since the eighties. He notes:

Perhaps we are now ready for an anthropology of and for resistance, which takes the diversity of images of the good life into fuller account when discussing resistance, so that it becomes a matter not just of refusal but of culturally inflected aspiration.

(Appadurai 2016: 3)

Geographical differences are vast after all - Central America, Europe, North America/Oceania, and Highland Asia. So too are languages, customs, dress, traditions, and religions - Talamanca is largely Evangelical and Pentecostal Christians, Baha'i and Roman Catholic, while Nagaland, Hawai'i and Sápmi are largely Protestant Christians. Thus, landscape and the way people relate to the environment again give rise to a diversity of worldviews. But yet there is a 
'common world' that people participate in through the discourse of 'indigeneity' however discrete, open, contested, fragile, or even adversarial. Nagas too participate in these ideas of indigeneity on different scales - ranging from the regional to the national to the United Nations (see Karlsson 2001, 2003). I may not be able to provide any certainty concerning Vechilu Rhakho's vision of how future Naga sovereignty will unfold through the involvement of United Nations Organisations, nor am I able to say how the reverberating effects of prayer for world leaders everyday at noon will bring sovereignty to fruition. It is even more difficult to conceptually think about the prophecy of me arriving at SAK and the effects of that on political events. Interesting, however, is what does that prophecy tell us about indigenous knowledge and its engagement with its futures, and my role in historicising, and perhaps, actualising it? But actuality is different from achieving sovereignty, as a finality that precludes becoming that 'keeps history open' and shifts our gaze from definite outcomes to the daily human struggle and grind that does not halt. I am left with more questions than answers but what I can say to Vechilu, Chungshi, and others with certainty is that Naga sovereignty and their struggles are now part of what James Clifford calls "worldmaking", where the peripheries are part of an alternative globalisation "from below" (2013: 310). From the vantage point of nation-states where the centre is typical and important, Nagaland, like Sápmi, Talamanca, and Hawai'i, appear remote, peripheral, and an exception. Many might think that the national frontier is where things cease. On the contrary, it is where things begin.

\section{Notes}

1 This chapter is dedicated to the memory of my father and the many of his generation who lived through one of the most tumultuous periods of Naga history. Their memories, strength, and resilience provide hope to generations. Thanks to Lindsay Graham, Jacob Copeman, Michael Heneise, and the numerous occasions the INREL-team discussed this paper, which made the chapter much, much better. Along Longkumer and Aheli Moitra accompanied me to the Shisha Hoho and asked insightful questions and provided wonderful company on a long, and bumpy, road journey.

2 Nagaland is predominantly Christian, with almost 95\%, mainly made up of Baptists (the majority) followed by the Roman Catholics, Revivalists, Presbyterians, and Pentecostals. Christianity arrived in the mid-19th century through the American Baptist Foreign Missionary Society (ABFMS) and through them the slow growth of Christianity ensued. The scale of Christian conversion increased when the Naga national struggle started, partly as a way to express a Christian identity as opposed to a Hindu one that was seen as complicit in aiding the Indian state to suppress the religion of the Nagas (see Longkumer 2019, 2018; Thomas 2016).

3 Usually a person who can see (through visions, dreams) the cause of an illness, foretell future events, and knows the precise sacrifice to be made to a deity in order to appease the deity.

4 The controversial 'Shillong Accord' was signed in Shillong (in the current state of Meghalaya) on 11th November 1975 between the Government of India and the Federal Government of Nagaland (the political wing of the NNC). This required the surrender and disarmament of the NNC and the de facto 'official' recognition of the constitution of India. 
5 Aheli Moitra, a journalist with Morung Express, accompanied me to Kütsapomi and here is her account (Moitra 2015).

\section{References}

Aier, Wati. 2011. "Naga Reconciliation and Peace (The Journey of Common Hope)". In Sitting Around the fire: A Dialogue on Politics, Peace, and Reconciliation. Dimapur: Morung Express.

Alemchiba, M. 1970. A Brief Historical Account of Nagaland. Kohima: Naga Institute of Culture.

Anderson, David G. 2000. Identity and Ecology in Arctic Siberia: The Number One Reindeer Brigade. Oxford: Oxford University Press.

Appadurai, Arjun. 1996. Modernity at Large: Cultural Dimensions of Globalization. Minneapolis: University of Minnesota.

Appadurai, Arjun. 2016. "Moodswings in the Anthropology of the Emerging Future". HAU: Journal of the Ethnographic Theory 6 (2): 1-4.

Bakhtin, M. M. 1981. The Dialogic Imagination: Four Essays. Translated by Caryl Emerson and Michael Holquist. Austin, TX: University of Texas Press.

Basso, Keith. 1996. Wisdom Sits in Places: Landscape and Language Among the Western Apache. Albuquerque: University of New Mexico Press.

Bear, Laura. 2016. "Time as Technique”. Annual Review of Anthropology 45: 487-502.

Biehl, Joao and Peter Locke. 2017. "Introduction: Ethnographic Sensorium". In Unfinished: The Anthropology of Becoming, edited by Joao Biehl and Peter Locke. Duke: Duke University Press, 1-38.

Bryant, Rebecca and Daniel M. Knight. 2019. The Anthropology of the Future. Cambridge: Cambridge University Press.

Carter, Paul. 1987. The Road to Botany Bay: An Essay in Spatial History. London: Faber \& Faber.

Chakrabarty, Dipesh. 2000. Provincializing Europe: Postcolonial Thought and Historical Difference. Princeton: Princeton University Press.

Clifford, James. 1997. Routes: Travel and Translation in the Late Twentieth Century. Cambridge: Harvard University Press.

Clifford, James. 2013. Returns: Becoming Indigenous in the Twenty-First Century. Cambridge: Harvard University Press.

Cody, Francis. 2011. "Publics and Politics". Annual Review of Anthropology 40: 37-52.

de Certeau, Michel. 1984. The Practice of Everyday Life. Translated by Steven Rendell. Berkeley, CA: University of California Press.

de la Cadena, Marisol. 2015. Earth Beings: Ecologies of Practice across Andean Worlds. Durham: Duke University Press.

Ferguson, James and Akhil Gupta. 2002. "Spatializing States: Toward an Ethnography of Neoliberal Governmentality”. American Ethnologist 29 (4): 981-1002.

Hannerz, Ulf. 1989. "Notes on the Global Ecumene". Public Culture 1 (2): 66-75.

Harvey, David. 1989. The Condition of Postmodernity. Cambridge, MA: Blackwell.

Herzfeld, Michael. 1997. Cultural Intimacy: Social Poetics in the Nation-State. New York: Routledge.

Ingold, Tim. 1993. "The Temporality of the Landscape". World Archaeology 25 (2): 24-174.

Ingold, Tim. 2000. The Perception of the Environment: Essays on Livelihood, Dwelling and Skill. London: Routledge. 
Jung, Courtney. 2008. The Moral Force of Indigenous Politics. Cambridge: Cambridge University Press.

Karlsson, Bengt G. 2001. "Indigenous Politics: Community Formation and Indigenous Peoples' Struggle for Self-determination in North-East India”. Identities: Global Studies in Culture and Power 8 (1): 7-45.

Karlsson, Bengt G. 2003. "Anthropology and the 'Indigenous Slot': Claims to and Debates about Indigenous Peoples' Status in India”. Critique of Anthropology 23 (4): 403-423.

Kearney, Michael. 1995. "The Local and the Global: The Anthropology of Globalization and Transnationalism". Annual Review of Anthropology 24: 547-565.

Klassen, Pamela. 2018. "Spiritual Jurisdiction". In Ekklesia: Three Inquiries in Church and State, edited by Paul Johnson, Pamela Klassen, and Winnifred Sullivan. Chicago: University of Chicago Press.

Latour, Bruno. 2004. "Whose Cosmos: Which Cosmopolitics? Comments on the Peace Terms of Ulrich Beck". Common Knowledge 10 (3): 450-462.

Lazar, Sian. 2014. "Historical Narrative, Mundane Political Time, and Revolutionary Moments: Coexisting Temporalities in the Lived Experience of Social Movements". Journal of the Royal Anthropological Institute (N.S.): 91-108.

Longkumer, Arkotong. 2018. "Bible, Guns and Land: Sovereignty and Nationalism amongst the Nagas of India". Nations and Nationalism 24 (4): 1097-1116.

Longkumer, Arkotong. 2019. “'Along Kingdom's Highway': The Proliferation of Christianity, Education, and Print amongst the Nagas in Northeast India, 1872-1955”. Contemporary South Asia 27 (2): 160-178.

Madianou, Mirca and Daniel Miller. 2012. "Polymedia: Towards a New Theory of Digital Media in Interpersonal Communication”. International Journal of Cultural Studies 16 (2): 169-187.

Maeckelbergh, Marianne. 2009. The Will of the Many: How the Alterglobalisation Movement Is Changing the Face of Democracy. London: Pluto.

Miyazaki, Hirokazu. 2004. The Method of Hope: Anthropology, Philosophy, and Fijian Knowledge. Stanford: Stanford University Press.

Moitra, Aheli. 2015. "Of Prophesy, Naga Unity \& the Legend of Kütsapomi”. Morung Express, published 1st May.

Muehlebach, Andrea. 2001. “'Making Place' at the United Nations: Indigenous Cultural Politics at the U.N. Working Group on Indigenous Populations". Cultural Anthropology 16 (3): 415-448.

Munn, Nancy. 1992. "The Cultural Anthropology of Time: A Critical Essay". Annual Review of Anthropology 21: 93-123.

Myint-U, Thant. 2011. Where China Meets India: Burma and the New Crossroads of Asia. London: Faber \& Faber.

Ortner, Sherry B. 2016. "Dark Anthropology and Its Others: Theory Since the Eighties". HAU: Journal of Ethnographic Theory 6 (1): 47-73.

Rabinow, Paul. 1996. Essays on the Anthropology of Reason. Princeton: Princeton University Press.

Riles, Annelise. 2000. The Network Inside Out. Ann Arbor: University of Michigan Press.

Sanyü, Visier and Richard Broome. 2018. A Naga Odyssey: My Long Way Home. New Delhi: Speaking Tiger Publishing Private Limited.

Sassen, Saskia. 1998. Globalization and Its Discontents. New York: The New Press.

Scott, James C. 2009. The Art of Not Being Governed: An Anarchist History of Upland Southeast Asia. New Haven: Yale University Press. 
Shaw, Karena. 2008. Indigeneity and Political Theory: Sovereignty and the Limits of the Political. Oxford: Routledge.

Stengers, Isabelle. 2005. "The Cosmopolitical Proposal". In Making Things Public, edited by Bruno Latour and Peter Weibel. Cambridge, MA: MIT Press, 994-1003.

Thomas, John. 2016. Evangelising the Nation: Religion and the Formation of Naga Political Identity. New Delhi: Routledge.

Tsing, Anna. 2000. “The Global Situation”. Cultural Anthropology 15 (3): 327-360.

Verghese, B. G. 1997. India's Northeast Resurgent: Ethnicity, Insurgency, Governance, Development. New Delhi: Konark Publishers.

Viveiros de Castro, Eduardo. 1998. "Cosmological Deixis and Amerindian Perspectivism". The Journal of the Royal Anthropological Institute 4 (3): 469-488. 